\title{
Peran Ayah dalam Pendidikan Anak Usia Dini di Era Digital
}

\author{
Suryadi $^{1}$, Desy Ayuningrum ${ }^{2}$, Nopiana ${ }^{3}$ \\ ${ }^{1}$ IAIN Metro Lampung, Indonesia \\ ${ }^{2}$ Fakultas Tarbiyah, Institut PTIQ Jakarta, Indonesia \\ ${ }^{3}$ Universitas Lampung, Indonesia \\ ${ }^{1}$ suryadi@metrouniv.ac.id \\ 22desyayuningrum@ptiq.ac.id \\ 3nopiana1201@fkip.unila.ac.id
}

\begin{abstract}
Abstrak
Anak usia dini merupakan individu yang berusia 0-6 tahun yang sedang mengalami proses perkembangan yang pesat. Anak-anak sangat identik dengan bermain. Dalam kegiatan seharihari anak sering melakukan permainan. Permainan yang dilakukan merupakan sesuatu yang dianggap wajib dilakukan sebagai sarana untuk perkembangan fisik motorik bagi anak usia dini. Seiring dengan kemajuan teknologi, di era digital saat ini anak biasanya melakukan permainan di gadget. Penelitian ini bertujuan untuk memperoleh gambaran mengenai perkembangan fisik motorik anak usia dini di era digital. Subjek penelitian ini terdiri dari 3 anak dengan rentang usia 5-6 tahun yang terdiri dari 1 anak laki-laki dan 2 anak perempuan. Hasil yang diperoleh dari penelitian ini adalah anak memperlihatkan perkembangan fisik dan motoriknya.
\end{abstract}

Kata Kunci: Peran ayah, Fisik Motorik, Permainan, Era Digital

\begin{abstract}
Early childhood is an individual who was starting from 0-6 years was having the process of the rapid development. The children were identical to play. In the child's daily activities often do thr game. The game is something that must be considered as a means to the development of the physical motor for early childhood. Along with technological progress, in the digital age at this time the child is usually done a game in gadget. This study aims to obtain a pictures of the development of the physcal motor early childhood in the digital age. The subject of this study
\end{abstract}


Suryadi, Desy Ayuningrum, Nopiana

consist of 3 children aged 5-6 years consisting of 1 boys and 2 girls. The result of derived from this research is the show the development of the physical and motor her.

Keywords: Father's role, Physical Motor, Games, Digital Age

\section{Pendahuluan}

Berbicara mengenai anak usia dini sangatlah menarik, untuk dibahas dan juga dipelajari. Namun, dengan adanya hal tersebut peran orang tua dalam mendidik anak sangatlah berguna dalam hal pendidikan anak itu sendiri. Apalagi bangaimana cara seorang ayah akan mendidik anaknya sendiri dalam hal perkembangan maupun keterampilan yang dimiliki sang anak. Terutama dalam hal fisik motorik pada anak usai dini. Kemajuan dan perubahan dalam berbagai sektor kehidupan memerlukan upaya pembinaan anak agar menghasilkan generasi muda yang berkepribadian unggul. Pembinaan atau pendidikan yang diterima anak pertama kali yaitu dari orang tua dalam lingkungan keluarga. Keluarga merupakan tempat dan lingkungan pendidikan pertama dan terutama bagi seorang anak, dan dari sana perkembangan kepribadian bermula. Orang tua mengajarkan kepada anak-anaknya penguasaan diri, nilai-nilai dan peran-peran sosial guna membentuk fondasi kepribadian yang lebih terarah.

Pada era digital ini, sangat mudah bagi orang tua untuk mengembangkan kemampuan dan keterampilan fisik motorik pada anak usia dini. Dengan melihat video maupun melakukan gerakan senam, atau bisa juga bermain olahraga lainnya yang dapat dilakukan bersama. Terutama bagi sang ayah yang bisa dilakukan bersama sang putra maupun putrinya. Kegiatan yang dilakukan sangat menyenangkan dan membuat sang anak merasa nyaman dan juga merasa gembira bisa bermain dengan sang ayah walaupun ayah yang sibuk bekerja.

Anak usia dini adalah individu yang berusia mulai dari 0-6 tahun yang sedang mengalami proses perkembangan dengan pesat. Pada usia 4-6 merupakan masa golden age bagi perkembangan anak usia dini di mana pada usia itu anak mampu menyerap hampir 50 persen dari apa yang dilihat dan didengarnya. Masa ini merupakan masa yang tepat untuk meletakkan dasar-dasar pengembangan kemampuan fisik, bahasa, sosial emosional, konsep diri, seni moral dan nilai-nilai agama. Pada tahap ini orang tua harus mampu bersikap dengan cara berbicara kepada anak, menanyakan pendapat anak, menciptakan suasana yang berwarnawarni sehingga anak nyaman bersama kita.

Lingkungan sosial yang pertama kali dikenal anak adalah keluarga yang merupakan lingkungan primer. Dalam keluarga, terdapat berbagai fungsi yang mempengaruhi perkembangan kepribadian para anggotanya, terutama anak. Menurut Soekanto, keluarga batih 
pada dasarnya mempunyai fungsi-fungsi sebagai berikut:

1. Unit terkecil dalam masyarakat yang mengatur hubungan seksual sewajarnya.

2. Wadah tempat terbentuknya sosialisasi, memahami menaati, dan menghargai kaidahkaidah serta nilai-nilai yang berlaku.

3. Unit terkecil dalam masyarakat yang memenuhi kebutuhan ekonomis.

4. Unit terkecil dalam masyarakat, tempat anggota-anggotanya mendapat perlindungan bagi ketenteraman dan perkembangan jiwanya ${ }^{1}$

Uraian tersebut menyoroti keluarga sebagai unit terkecil dari masyarakat yang di dalamnya terdapat kesatuan intim, untuk melanjutkan keturunan, tempat berlangsungnya sosialisasi anak, tempat pemenuhan kebutuhan ekonomis dan tempat anggota-anggotanya mendapatkan perlindungan bagi ketenteraman dan perkembangan jiwanya. Sebagai lingkungan pendidikan primer, keluarga terutama orang tua memiliki peran yang penting dalam kehidupan anak, sebab perkembangan kepribadian mereka dimulai dari proses sosialisasi yang terjadi antara anak dan orang tua dalam lingkungan keluarga. Khairuddin menambahkan bahwa fungsi sosialisasi menunjuk peran orang tua dalam membentuk kepribadian anak, melalui proses sosialisasi. Dalam lingkup keluarga, anak mempelajari pola-pola tingkah laku, sikap, keyakinan, cita-cita, dan nilai-nilai dalam masyarakat dalam kerangka perkembangan kepribadian anak. ${ }^{2}$

Proses sosialisasi akan berjalan baik apabila antara ayah dan ibu sebagai orang tua bisa menjalankan fungsinya dengan baik pula. Antara ayah dan ibu tercipta pola hubungan kemitraan (partnership) di mana ayah ibu memiliki hak yang sama dalam mengelola rumah tangga terutama mendidik anak-anak. Ayah (suami) melakukan peran publik dan domestik. Artinya kendatipun ayah berperan sebagai pencari nafkah, dalam hal urusan rumah tangga yang menjadi pekerjaan ibu, ayah mampu melakukannya juga.

Kewajiban orang tua dalam mendidik sang anak orang tua terdiri dari ayah dan ibu yang mana ayah adalah seseorang yang bertanggung jawab dalam suatu rumah tangga, dan ibu adalah seseorang yang melahirkan seorang anak dan mengurus rumah tangga. Mereka adalah figur atau contoh yang akan selalu ditiru oleh anak-anaknya. Orang tua bertanggung jawab di dalam mengasuh dan mendidik anaknya hingga dewasa. Pola asuh orang tua adalah pola perilaku yang diterapkan pada anak dan bersifat relatif konsisten dari waktu ke waktu.

\footnotetext{
${ }^{1}$ Soerjono Soekanto, Sosiologi keluarga tentang ikhwal keluarga, remaja, dan anak (Rineka Cipta, 1990), 2.

${ }^{2}$ Khairuddin, Sosiologi Keluarga (Jakarta: Nur Cahaya, 1985), 60; Acmad Hidir dan Bayu Anggara, "Gugat Cerai Dikalangan Masyarakat di Kenagarian Batu Bulek Kecamatan Lintau Buo Utara Kabupaten Tanah Datar Provinsi Sumatera Barat Gugat Cerai Dikalangan Masyarakat di Kenagarian Batu Bulek Kecamatan Lintau Buo Utara Kabupaten Tanah Datar Provinsi Sum," Jurnal Online Mahasiswa Fakultas Ilmu Sosial dan Ilmu Politik Universitas Riau 2, no. 1 (Februari 2015).
} 
Tanggung jawab keluarga khususnya orang tua dalam pendidikan anak saat ini sangat besar. Dalam hal tersebut tidak luput dari peran seorang ayah dalam mendidik anaknya. Terutama dalam perkembangan fisik motorik anaknya, untuk mengembangkan keterampilan fisik motorik pada anak usia dini sebetulnya hal yang mudah dan dapat dilakukan di rumah. Pada masa sekarang yang harus bekerja dan belajar di rumah merupakan hal yang wajar dan perlu dilakukan. Peran ayah dalam mengembangkan keterampilan fisik motorik anak baik perempuan maupun laki-laki, mudah dilakukan bersama dengan meluangkan waktu yang ada di setiap hari maupun kesempatan yang ada. Secara detail, pengaruh keterlibatan ayah dalam perkembangan anaknya meliputi banyak hal, seperti kognitif, emosional, sosial, bahkan juga bisa mempengaruhi kesehatan fisik. ${ }^{3}$ Dari segi kognitif, keterlibatan ayah dalam kegiatan bermain maupun pengasuhan dan perawatan anak akan membuat anaknya lebih kompeten dan menjadi pemecah masalah yang lebih baik jika dibandingkan dengan anak sebayanya yang ayahnya tidak memiliki keterlibatan. Kebiasaan para ayah untuk mengajukan pertanyaan logis seperti apa, di mana, dan seterusnya, membuat anak memiliki keterampilan komunikasi yang lebih baik dalam interaksinya. Anak akan lebih terpancing untuk banyak berbicara, menggunakan kosakata yang lebih banyak, dan menghasilkan kalimat yang lebih panjang ketika berinteraksi dengan anaknya.

Dari segi emosional, anak memiliki kedekatan yang lebih banyak dari ayahnya, memiliki rasa lebih nyaman. Selain itu, anak juga memiliki rasa ingin tahu dan keinginan untuk mengeksplorasi apa yang ada di lingkungannya, bisa berinteraksi dan memberikan respons pada stimulus dan ia juga memiliki kepercayaan diri yang lebih baik. Ditinjau dari segi sosial, keterlibatan ayah membuahkan kompetensi sosial, inisiatif, kematangan sosial, dan kemampuan untuk berinteraksi sosial pada anaknya. Hubungan anak dengan teman sebayanya juga lebih baik. Dalam pertemanan anak cenderung positif terhadap anak lain termasuk saudara kandungnya, bisa menyelesaikan konflik pertemanan yang dialami cara yang positif Tinjauan secara kesehatan fisik juga menunjukkan dampak yang positif, bahkan sejak anak masih dalam kandungan. Perhatian yang diberikan seorang ayah pada pasangannya memberkan nuansa positif dalam kehidupan rumah tangga dan membuat kesehatan ibu-anak menjadi lebih diperhatikan. Secara umum, ayah yang melibatkan diri dalam kegiatan bersama dengan anaknya memiliki anak yang lebih sehat dan relatif tidak terlalu sering mengalami masalah kesehatan.

Keterlibatan ayah dalam hal mendidik dan juga mengasuh sang anak sangatlah sedikit

\footnotetext{
${ }^{3}$ Sarah Allen dan Kerry J. Daly, “The effects of father involvement,” An Updated Research Sum, 2007.
} 
bahkan terkadang bagi ayah yang sibuk akan bekerja dan mendidik anak sangat berpengaruh. Peranan ayah dalam keluarga yang pertama adalah sebagai pencari nafkah bagi keluarga. Dua dari lima subjek dalam penelitian ini merupakan pencari nafkah utama dalam keluarga, sedangkan tiga subjek lainnya istri ikut terlibat dalam mencari nafkah. Peran ayah dalam mencari nafkah dilakukan kelima subjek untuk memenuhi kebutuhan rumah tangga serta demi kelangsungan hidup mereka. Rasa tanggung jawab sebagai seorang ayah dalam memenuhi kebutuhan rumah tangga membuat para ayah lebih banyak meluangkan waktunya di luar rumah sehingga keterlibatannya dalam mengasuh anak menjadi sedikit. Peran ayah yang kedua adalah kebersamaan antara ayah dan anak. Meskipun ayah sebagai pencari nafkah serta lebih banyak meluangkan waktu di luar rumah bukan berarti ayah tidak memiliki waktu bersama dengan anak. Kebersamaan antara ayah dan anak sekedar kegiatan bermain, jalanjalan ataupun membelikan anak mainan. Hal ini serupa dengan jawaban yang diberikan kelima subjek yang mengatakan bahwa mereka sering mengajak anak jalan-jalan ataupun bermain. Kebersamaan antara ayah dan anak dibatasi oleh waktu dikarenakan ayah harus bekerja sehingga tidak memiliki banyak waktu untuk berada di rumah kecuali pada hari libur.

Peran ayah yang ketiga adalah sebagai pengasuhan. Pengasuhan anak bukan hanya keterlibatan seorang ibu namun juga ayah ikut terlibat di dalamnya. Pengasuhan antara ayah dan ibu sebenarnya sama hanya saja kuantitas dan kualitasnya berbeda. Peran ayah yang keempat adalah sebagai guru atau pembimbing. Ada ungkapan yang mengatakan bahwa ibu sebagai madrasatul ula yang artinya ibu sekolah pertama bagi anak, namun bukan berarti ibu satu-satunya orang tua yang dapat menjadi guru bagi anak. Ayah juga dapat ikut andil dalam memberikan layanan pendidikan bagi anak. Tiga dari lima subjek menyatakan keterlibatannya dalam kegiatan belajar dengan anak di antaranya adalah mengajarkan anak mengaji dan membantu anak belajar atau sekedar menemani anak menggambar. Sedangkan dua lainnya menyerahkan masalah pendidikan anak kepada sang istri. Peran ayah yang kelima adalah sebagai orang yang mendukung segala kegiatan anak. Meskipun para ayah lebih banyak meluangkan waktu di luar rumah bukan berarti mereka tidak mengetahui segala aktivitas yang dilakukan oleh anak. Ibu menjadi penghubung antara ayah dan anak, ibu sebagai orang yang selalu berada dengan anak akan menyampaikan kepada ayah mengenai perkembangan dan segala kegiatan yang telah anak lakukan. Ayah akan selalu mendukung segala kegiatan yang dilakukan anak selama kegiatan tersebut positif dan tidak merugikan bagi anak, meskipun ayah tidak terlibat dalam kegiatan anak. Seperti yang diungkapkan oleh kelima subjek, mereka mengatakan bahwa selalu mendukung segala kegiatan yang dilakukan oleh anak. Satu dari lima subjek menyatakan bahwa dirinya sering terlibat setiap kegiatan yang dilakukan 
anak di sekolah seperti kegiatan pawai, kegiatan menari dan kegiatan perlombaan. Namun empat lainnya menjawab jarang terlibat langsung bersama anak tetapi tetap mendukung aktivitas anak.

Dalam menstimulasi perkembangan fisik motorik pada anak usia 4-6 tahun merupakan hal yang lumrah dalam memberikan arahan serta stimulasi yang tepat bagi orang tua, terutama bagi ayah. Dengan, mengajarkan perkembangan fismot pada anak itu tidak mudah dengan meluangkan waktu yang ayah miliki untuk mengembangkan fismot sang anak. Baik, dari perkembangan motorik halus maupun motorik kasar yang diajarkan. Perkembangan motorik halus pada anak usia 4 tahun sangat berkembang bahkan hampir sempurna, pada usia 4 tahun anak mampu melakukan loncatan dan lompatan satu kaki dengan lancar serta mampu menangkap bola dengan baik, pada anak usia 5 tahun telah mampu mengkoordinasikan gerakan visual motorik seperti mengkoordinasikan gerakan tangan, lengan dan tubuh secara bersama, perkembangan motorik halus jelas terbukti pada peningkatan keterampilan anak seperti menggambar dan berpakaian. Pada usia anak 4-5 tahun perkembangan yang paling menonjol adalah motorik.

Penelitian yang dilakukan oleh Dewi Erina Rifdiastuty ${ }^{4}$, dengan judul pengaruh Clay Therapi terhadap perkembangan motorik halus pada anak prasekolah usia 4-5 tahun di TK Mekar Sari Kendal tujuan penelitian ini untuk mengetahui pengaruh clay therapi terhadap motorik halus pada anak prasekolah usia 4-5 tahun di TK mekar sari kendar. Desain penelitian ini adalah quasi eksperimen menggunakan rancangan penelitian one gruop pretest-postest design. Jumlah sampel 30 anak dengan teknik total sampling berdasarkan distribusi motorik halus responden sebelum diberikan clay therapi sebanyak 16 responden $(50,3 \%)$ berapa pada tahap perkembangan dan setelah diberikan clay therapi sebanyak 14 responden (46,7\%) mengalami peningkatan dari terlambat menjadi melebihi setelah diberikan clay therapi sebanyak 3 kali ada pengaruh clay therapi terhadap perkembangan motorik halus di TK mekar sari kendal dengan nilai z $(3,358)$ dan nilai signifikan $\mathrm{c}=0,001$.

Sedangkan, penelitian yang dilakukan oleh Imelda ${ }^{5}$, dengan judul pengetahuan ibu tentang pemberian stimulasi dan perkembangan anak prasekolah (3-5 tahun), tujuan penelitian untuk mengetahui hubungan pengetahuan ibu tentang tantang pemberian stimulasi dengan

\footnotetext{
${ }^{4}$ Dewi Erina Rifdiastuty, Dera Alfiyanti, dan Eko Purnomo, "PENGARUH CLAY THERAPY TERHADAP PERKEMBANGAN MOTORIK HALUS PADA ANAK PRASEKOLAH USIA 4-5 TAHUN DI TK MEKARSARI KENDAL," Karya Ilmiah, 2015.

5 Imelda Imelda, "PENGETAHUAN IBU TENTANG PEMBERIAN STIMULASI DAN PERKEMBANGAN ANAK PRA SEKOLAH (3-5 TAHUN) DI BANDA ACEH," Idea Nursing Journal 8, no. 3 (2017).
} 
perkembangan anak pra sekolah di Banda Aceh, hasil penelitian menunjukkan ada hubungan pengetahuan ibu tentang stimulasi motorik kasar (p-value 0,005), motorik halus ( $p$-value 0,002), stimulasi bahasa ( $p$-value 0,001), stimulasi sosial (p-value 0,003) dengan perkembangan anak pra sekolah. Melalui penelitian ini, peneliti menyarankan kepada fakultas keperawatan, agar dapat bekerja sama dengan pihak kader desa dan puskesmas terkait dalam hal sosialisasi stimulasi perkembangan pada anak pra sekolah. Berdasarkan, penelitian yang telah dilakukan ternyata masih banyak peran seorang ibu dalam memberikan stimulasi fisik motorik pada anak usia pra sekolah. Namun, juga tidak sedikit peran sang ayah dalam hal memberikan stimulasi bagi anaknya.

Maka, dalam hal tersebut artikel ini akan dibahas seberapa besar peran ayah dalam mendidik anaknya pada perkembangan fisik motoriknya. dan juga seberapa persentase yang telah diperoleh berdasarkan survei yang dilakukan. Peran ayah dalam perkembangan fisik motorik anak dan juga seberapa persen ayah yang memiliki waktu pada anaknya, atau juga yang sibuk bekerja tidak memiliki waktu bagi anaknya. Penelitian ini ditujukan untuk anak usia 4-5 tahun yang pada umumnya memiliki jiwa yang sangat aktif dan juga sulit untuk bisa diam.

\section{Metode Penelitian}

Dalam, melakukan penelitian ini dengan metode kualitatif, di mana dengan teknik penelitian berupa observasi, eksperimen dan juga melakukan pengamatan secara langsung terhadap objek yang akan diteliti. metode ini juga, melihat arah permasalahan untuk membuat deskripsi, gambaran atau melukiskan sesuatu secara sistematis, aktual dan akurat mengenai fakta-fakta tentang peran yang dilakukan ayah dalam kehidupan anaknya khususnya dalam perkembangan dan pendidikannya. Agar dalam penelitian ini, mendapatkan informasi yang relevan dan sistematis maka dapat dikatakan sumber informan dalam penelitian ini adalah;

1. Peran ayah dalam mendidik keterampilan fisik motorik di era digital ini

2. Seberapa ayah mempunyai waktu untuk anaknya, dalam mengembangkan keterampilan fismot sang anak

Dalam, melakukan penelitian ini penulis mengambil data atau tempat di desa sebagai objek yang akan diteliti. Dengan mengambil sampel antara 10-15 orang ayah yang ada pada desa Sumber Baru kecamatan Mesuji Raya kabupaten Komering Ilir, Sumatera Selatan. tersebut. waktu yang digunakan itu kisaran antara 1 minggu untuk melakukan pengamatan maupun hal lainnya yang dibutuhkan dalam melakukan prosedur penelitian. Untuk melakukan penelitian ini, penulis melakukan beberapa prosedur untuk penelitian ini, antara lain; 
1. Wawancara secara terbuka

Di mana dalam melakukan wawancara ini, merupakan suatu teknik dengan memberikan pertanyaan langsung dengan informan mengenai pokok pembahasan penelitian, kemudian pewawancara mencatat atau merekam jawaban-jawaban yang dikemukakan oleh informan. Wawancara ini digunakan dengan menggunakan pedoman wawancara yang bertujuan untuk mendapatkan keterangan berdasarkan masalah penelitian.

2. Observasi

Teknik ini digunakan untuk menghimpun keterangan yang diakukan dengan mengadakan pengamatan dan pencatatan secara sistematis terhadap fenomena yang akan dijadikan objek pengamatan. Tenik akan mendukung data yang diperoleh melalui wawancara, sehingga akan diketahui apakah data yang akan diberikan informan sesuai dengan keadaan sebenarnya. Selain itu pengamatan langsung yang dilakukan yaitu dengan mengamati obyek penelitian yang berupa keterlibatan yang dilakukan ayah dalam pendidikan dan keterampilan fismot di era digital ini.

3. Studi Dokumen

Teknik yang digunakan dapat berupa gambar maupun hal lainnya, yang dapat digunakan sebagai analisis data. Di mana penulis lebih kepada dokumentasi atau hal yang dilakukan ayah untuk mendidik dan mengajarkan keterampilan fismot pada anak usia 4-6 tahun. Interaksi antara ayah dan anak dalam melakukan kegiatan bersama untuk mengembangkan keterampilan fismot.

Menurut Natsir analisis data adalah kegiatan mengelompokkan, membuat suatu ukuran manipulasi serta mengangkat data sehingga mudah untuk dibaca. Teknik analisa data yang digunakan adalah analisis kualitatif. Analisis kualitatif digunakan untuk menjelaskan, mendeskripsikan serta menafsirkan hasil penelitian dengan susunan kata dan kalimat sebagai jawaban atas permasalahan yang diteliti. Data yang diperoleh dari wawancara mendalam diolah dan dianalisis secara kualitatif dengan proses reduction dan interpretation. Data yang terkumpul ditulis dalam bentuk transkripsi, kemudian dilakukan pengkategorian dengan melakukan reduksi data yang terkait, kemudian dilakukan interpretasi yang mengarah pada fokus penelitian. ${ }^{6}$

\section{Hasil Dan Pembahasan}

${ }^{6}$ Moh Natsir, “MetodePenelitian,” Jakarta: Ghalia Indonesia, 1998. 
Berdasarkan data yang sudah diperoleh bahwa melalui teknik pengumpulan data berupa studi dokumen dapat dikatakan bahwa seorang ayah yang memiliki peran sebagai pekerja dan juga yang memiliki waktu di tengah kesibukan sang ayah sendiri itu sangat banyak. dari yang berangkat kerja pukul 07.00 sampai pukul 05.00 dan bahkan ada yang pulang sampai larut malam. sebagai orang tua atau ayah mereka masih memiliki waktu yang cukup untuk memberikan pembelajaran bagi sang anak. Dari hasil yang diobservasi bahwa penelitian ini, terdapat 3 sampel yang pertama tampak bahwa bapak Herman Purnama dan putranya yang bermana Aska Fahreza Purnama.

Gambar 1. Ayah sedang mengajarkan senam kepada anak

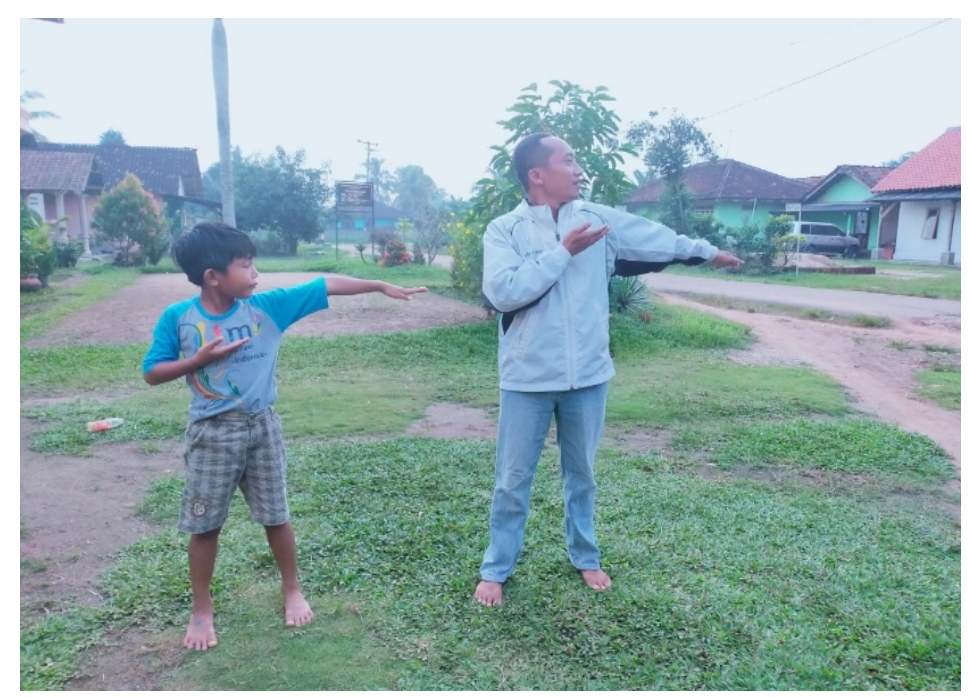

Sumber: Dokumentasi Pribadi

Seperti yang telah digambarkan pada gambar yang menunjukkan sang anak dan ayah yang sedang berlatih senam setiap sore maupun pagi, untuk mengajarkan fismot pada anak laki-lakinya. Tampak pada gambar bahwa seorang ayah yang bekerja dari pagi sampai dengan sore masih sempat mengajarkan stimulasi fisik motorik pada sang anak. Pada era digital ini bagi sang ayah tidak harus melakukan hal yang terkait dengan iptek maupun bisa juga dengan melihat Youtube untuk melihat gerakan yang sesuai bagi anak menurut keterangannya.

Gambar 2. Ayah mengajarkan menulis kepada anak 


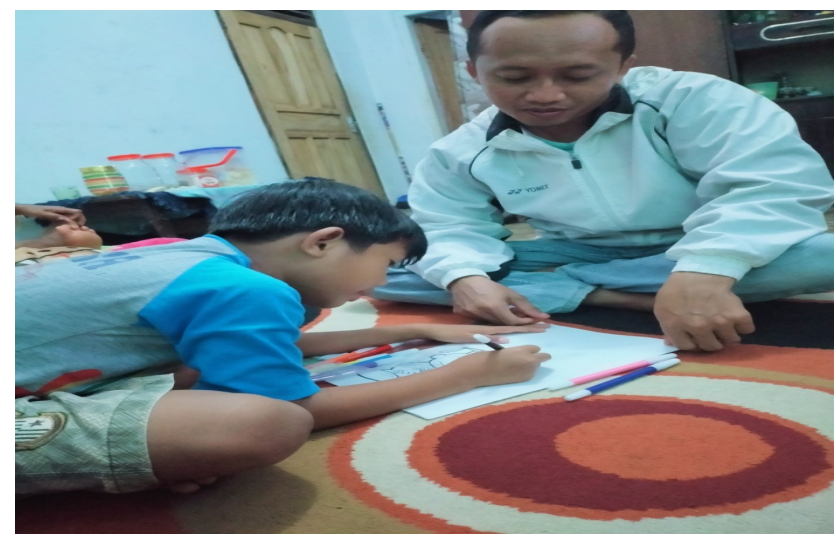

Sumber: Dokumentasi Pribadi

Pada gambar tampak bahwa ayah yang sama juga sedang mengajarkan menulis pada anak laki-lakinya. dengan jadwal kerja ayah tersebut ayah tidak mempunyai banyak waktu senggang seperti ibu yang bisa lebih banyak menghabiskan waktu dengan anaknya, akan tetapi ayahnya tetap masih menyempatkan waktu untuk bermain atau sekedar bercanda dengan anaknya, teradang setelah lepas magrib pun ayahnya menyempatkan waktu mengajari anak seperti menulis atau menggambar, agar melatih motorik halus pada anak, walaupun tidak setiap hari kegiatan tersebut bisa ayahnya lakukan, karena terkadang ayah kelelehan selepas bekerja pulang dari sawah. Terkadang ayah juga mengajarkan anak mengaji atau mengulasnya, karena si anak belajar mengaji di saat sore hari sekitar jam 04.00 di rumah pakdenya, jadi ayahnya hanya mengulas bagaimana mengaji tadi. Dan di setiap sore setelah ayah pulang kerja ia terkadang mengajak anak senam atau bermain bola atau bermain bulu tangkis untuk menghabiskan waktu bersama anaknya dan juga untuk melatih motorik kasar anak tersebut agar dapat berkembang dengan maksimal.

Selanjutnya, hasil dari penelitian sampel yang kedua tampak bahwa ayah yang sudah pulang bekerja sedang mengajarkan sang anak untuk menulis. Bapak Ridwan yang setiap hari bekerja pulang hingga sore, masih sempat untuk mengejarkan putrinya yang bernama Aqila yang saat ini berusia 5 tahun. Dengan, begitu sang ayah masih sempat untuk mengajarkan sang anak untuk belajar menulis.

Gambar 3. Ayah mengajarkan menulis pada anak perempuannya 


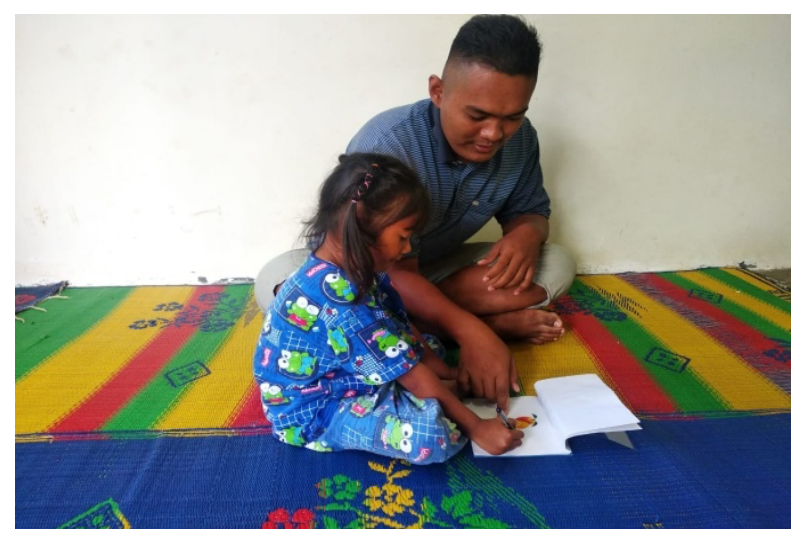

Sumber: Dokumentasi Pribadi

Gambar yang kedua, bahwa bapak Ridwan juga mengajarkan stimulus fisik motorik pada anaknya sendiri. selanjutnya, terlihat seperti gambar di bawah ini.

Gambar 4. Ayah yang mengajarkan anak bermain bola

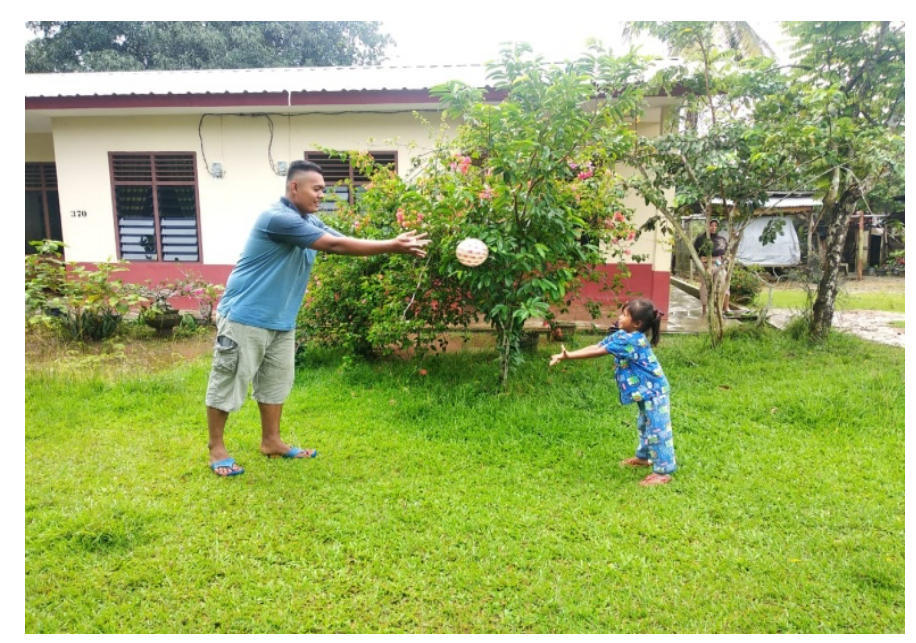

Sumber: Dokumentasi Pribadi

Macam-macam permainan kecil yang menggunakan bola, di antaranya adalah lari bolak-balik sambil memindahkan bola, melemparkan bola ke dalam keranjang, lempar tangkap bola, menggelindingkan bola. Permainan yang menggunakan bola, menurut pendapat dari Sujiono, tidak memerlukan keterampilan tingkat tinggi, dan memungkinkan semua anak terlibat ke dalamnya, sehingga anak mampu merespons aktivitas dengan gembira, dapat digunakan secara individu maupun kelompok, dapat disesuaikan dengan tingkat perkembangan anak, dapat menyalurkan energi dan aspirasi anak, melalui aktivitas melempar, menangkap, menggelindingkan, dan melambungkan, dapat melibatkan seluruh anak untuk berpartisipasi 
aktif. Tinjauan proses pembelajaran dengan menggunakan media bola besar sebagai upaya untuk meningkatkan motorik kasar anak. Peranan media bola dalam membantu meningkatkan kemampuan motorik kasar anak dapat dilakukan melalui kegiatan, seperti menangkap bola yang dilakukan seperti gambar di atas. Kegiatan di atas sangat bermanfaat bagi stimulus perkembangan sang anak.

Gambar 5. Ayah sedang menunjukkan video kepada anak perempuan

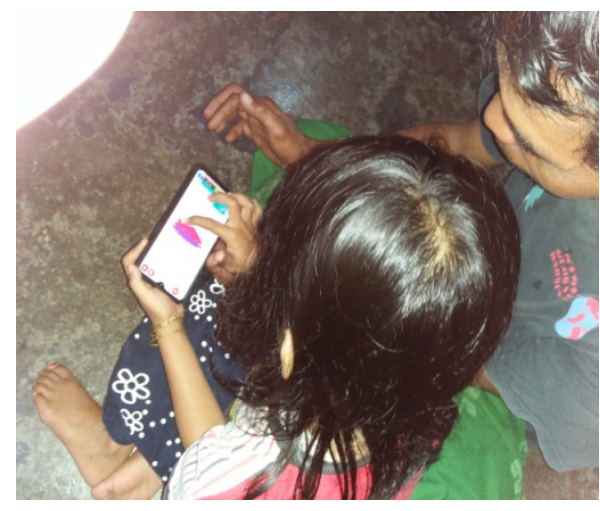

Sumber: Dokumentasi Pribadi

Ayah yang sedang memperhatikan atau sedang bermain video game, kepada anak perempuannya. salah satu kegiatan yang dilakukan pada saat sang ayah pulang. dengan begitu, pada masa era digital yang mengharuskan setiap detik harus menggunakan kemampuan yang mudah dan cepat saat ini. Pada masa digital ini kemampuan yang bisa dilakukan itu sangat mudah untuk melatih perkembangan fisik motorik sang anak. Salah satunya seperti gambar di atas yang menunjukkan bapak Wawan dengan putrinya bermain vedio game. Namun, dengan anak yang terus menerus diberikan permainan yang berbasis gadget akan juga memiliki dampak yang sangat berbahaya bagi pertumbuhan sang anak. Terang sang ayah sendiri bahwa setiap ada waktu beliau akan melatih keterampilan fisik motorik dengan bermain video game. Kata beliau juga tidak sering anaknya diberikan hp terus menerus, tetapi hanya sesekali akan diberikan.

Dari hasil penelitian yang telah dilakukan bahwa dapat dikatakan walau sang ayah yang sibuk bekerja tetapi masih sempat memiliki waktu bermain atau mengajarkan stimulus perkembangan fisik motorik pada anaknya. Sekitar 90\% kegiatan ayah dalam pendidikan anak usia dini dilakukan bersama dengan sang anak. Sedangkan sisanya tidak memiliki waktu untuk bermain bagi sang anak. terdapat 3 rumah yang sudah kami teliti bahwa sang ayah tidak memiliki waktu bermain bagi sang anak. Ayah yang terlalu sibuk terhadap kegiatan yang dilakukan untuk bekerja. Namun, di samping itu juga dapat dikatakan bahwa ayah yang 
memiliki waktu untuk sanga anak juga banyak, disela kegiatan yang padat ayah juga memiliki waktu yang relevan terhadap sang anak.

Salah satu aktivitas rutin yang dilakukan oleh anak adalah menulis dan mewarnai agar anak lebih antusias dan senang dalam kegiatan belajar menulis, orang tua harus menyiapkan media yang menarik. Salah satu media yang cocok dalam mengajari anak menulis adalah dengan media gambar. Aktivitas mewarnai lazimnya sudah menjadi bagian dari kehidupan anak-anak, bukan hanya sebagai kegiatan untuk mengisi waktu kosong anak, tapi juga sebagai aktualisasi diri anak dalam bidang seni. Apalagi gambar yang diwarnai anak adalah hasilnya sendiri, maka akan lebih terlihat imajinasi dan pikiran anak. Dalam aktivitas mewarnai, setiap anak memiliki kemampuan yang berbeda dalam hal mewarnai, ada anak yang dapat mewarnai dengan kombinasi warna yang bervariasi, ada pula yang mewarnai satu objek dengan satu warna saja. Perkembangan motorik halus berkaitan dengan kegiatan meletakkan atau memegang suatu obyek dengan jari-jari tangan. Stimulasi perkembangan motorik halus bertujuan melatih jari-jemari anak untuk persiapan menulis, seperti mengunting, menjiplak mewarnai. Di era digital saat ini, orang tua dapat memanfaatkan teknologi sekarang dengan mengembangkan kemampuan motorik halus anak dengan game di gadget seperti yang terlihat pada gambar di atas. Tetapi ayah juga bisa mengajarkan anak menulis atau mewarnai dengan kertas dan alat tulis, contoh ini dapat kita lihat pada gambar di atas.

Berdasarkan keterangan yang diperoleh dari ketiga informan dapat terlihat bahwa secara fisik, keterlibatan ayah dalam kehidupan keluarganya menunjukkan dampak yang positif. Partisipasi dan perhatian yang diberikan ayah dari anak masih dalam kandungan hingga ibu melahirkan sampai berusia balita memberikan dampak yang baik khususnya bagi kesehatan ibu dan anak. Dari informan yang kami dapatkan dalam penelitian ini dapat dikatakan bahwa dalam perkembangan fisik motorik sang anak sangat berlaku pada pendidikan anak diera digital ini. dengan adanya keterlibatan langsung sang ayah walau sibuk anak akan merasa lebih senang dengan apa yang telah ayah lakukan untuk sang anak. Dapat disimpulkan bahwa antara kenyataan di lapangan dengan teori yang ada terdapat kesesuaian, seperti teori yang dikemukakan oleh Allen dan Dally. ${ }^{7}$ Tinjauan secara kesehatan fisik juga menunjukkan dampak yang positif, bahkan sejak anak masih dalam kandungan. Perhatian yang diberikan seorang ayah pada pasangannya memberikan nuansa positif dalam kehidupan rumah tangga dan membuat kesehatan ibu-anak menjadi lebih diperhatikan. Secara umum, ayah yang

\footnotetext{
${ }^{7}$ Allen dan Daly, "The effects of father involvement."
} 
melibatkan diri dalam kegiatan bersama dengan anaknya memiliki anak yang lebih sehat dan relatif tidak terlalu sering mengalami masalah kesehatan.

Dampak yang sangat baik bagi pertumbuhan dan juga perkembangan fisik motorik sang anak. jikalau, sang ayah yang sangat sibuk dan tidak memperhatikan perkembangan fisik motorik yang terjadi pada anaknya sendiri. Pada era digital juga dapat mempengaruhi perkembangan sang anak, termasuk dalam perkembangan fisik motorik. Namun, sebiasa mungkin orang tua jangan terlalu memberikan hp kepada anak dapat merusak mata sang anak terutama pada anak usia dini sendiri. Masih banyak permainan yang dapat dilakukan bersama contohnya seperti gambar di atas. Seperti itu, kegiatan yang dapat dilakukan bersama dengan sang ayah di rumah, contohnya saja bermain lempar bola, menulis dan juga mewarnai maupun kegiatan yang lainnya membaut anak akan semakin tertarik terhadap kegiatan untuk membantu stimulus perkembangan psikomotorik anak usia dini pada era digital ini.

Dalam penelitian ini dapat disimpulkan bahwa peran ayah dalam mendidik anak dan mengembangkan psikomotorik anak dapat dikatakan sangat baik, karena walaupun sang ayah bekerja dari hari Senin hingga Sabtu sang ayah masih menyempatkan waktu untuk menemani anak bermain ketika sang ayah sudah pulang kerja. Dan tak lupa juga ayah mengajarkan anak mengaji. Dan pada hari minggu saat sang ayah libur bekerja juga sang ayah full day untuk anaknya, sehingga sang anak merasa senang dan nyaman saat bersama ayah. Dan anak pun tampak merasa sangat diperhatikan sekali oleh sang ayah. Dengan begitu perkembangan anak sangat baik sekali karena sang ayah yang selalu meluangkan waktu pas libur kerja untuk anak dan sang ayah selalu memberikan Stimulus kepada anak untuk perkembangannya. Jadi anak dapat berkembang dengan sangat baik dan mendapatkan kasih sayang yang utuh dari kedua orang tuanya.

\section{Kesimpulan}

Peran orangtua dalam mendidik anak sangatlah penting dan berguna dalam hal pendidikan anaknya. Apalagi bangiamana cara seorang ayah akan mendidik anaknya sendiri dalam hal perkembangan maupun keterampilan yang dimiliki sang anak. Terutama dalam hal fisik motorik pada anak usai dini. Pembinaan atau pendidikan yang diterima anak pertama kali yaitu dari orang tua dalam lingkungan keluarga. Keluarga merupakan tempat dan lingkungan pendidikan pertama dan terutama bagi seorang anak, dan dari sana perkembangan kepribadian bermula. Pada era digital ini, sangat mudah bagi orangtua untuk mengembangkan kemampuan dan keterampilan fisik motorik pada anak usia dini. Dengan melihat vidoe maupun melakukan 
gerakan senam, atau bisa juga bermain olahraga lainnya yang dapat dilakukan bersama. Terutama bagi sang ayah yang bisa dilakukan bersama sang putra maupun putrinya.

Secara fisik, keterlibatan ayah dalam kehidupan keluarganya menunjukkan dampak yang positif. Partisipasi dan perhatian yang diberikan ayah dari anak masih dalam kandungan hingga ibu melahirkan sampai berusia balita memberikan dampak yang baik khususnya bagi kesehatan ibu dan anak. Perhatian yang diberikan seorang ayah pada pasangannya memberikan nuansa positif dalam kehidupan rumah tangga dan membuat kesehatan ibu dan anak menjadi lebih diperhatikan. Dampak yang sangat baik bagi pertumbuhan dan juga perkembangan fisik motorik sang anak. jikalau, sang ayah yang sangat sibuk dan tidak memperhatikan perkembangan fisik motorik yang terjadi pada anaknya sendiri. Pada era digital juga dapat mempengaruhi perkembangan sang anak, termasuk dalam perkembangan fisik motorik

\section{Daftar Pustaka}

Acmad Hidir dan Bayu Anggara. "Gugat Cerai Dikalangan Masyarakat di Kenagarian Batu Bulek Kecamatan Lintau Buo Utara Kabupaten Tanah Datar Provinsi Sumatera Barat Gugat Cerai Dikalangan Masyarakat di Kenagarian Batu Bulek Kecamatan Lintau Buo Utara Kabupaten Tanah Datar Provinsi Sum.” Jurnal Online Mahasiswa Fakultas Ilmu Sosial dan Ilmu Politik Universitas Riau 2, no. 1 (Februari 2015).

Allen, Sarah, dan Kerry J. Daly. "The effects of father involvement." An Updated Research Sum, 2007.

Imelda, Imelda. "PENGETAHUAN IBU TENTANG PEMBERIAN STIMULASI DAN PERKEMBANGAN ANAK PRA SEKOLAH (3-5 TAHUN) DI BANDA ACEH.” Idea Nursing Journal 8, no. 3 (2017).

Khairuddin. Sosiologi Keluarga. Jakarta: Nur Cahaya, 1985.

Natsir, Moh. “MetodePenelitian.” Jakarta: Ghalia Indonesia, 1998.

Rifdiastuty, Dewi Erina, Dera Alfiyanti, dan Eko Purnomo. "PENGARUH CLAY THERAPY TERHADAP PERKEMBANGAN MOTORIK HALUS PADA ANAK PRASEKOLAH USIA 4-5 TAHUN DI TK MEKARSARI KENDAL.” Karya Ilmiah, 2015.

Soekanto, Soerjono. Sosiologi keluarga tentang ikhwal keluarga, remaja, dan anak. Rineka Cipta, 1990. 
Suryadi, Desy Ayuningrum, Nopiana

294 | IQ (Ilmu Al-qur'an): Jurnal Pendidikan Islam| Volume 3 No.02 2020 